\title{
Records of growth and development data in the child health handbook
}

\author{
Registro dos dados de crescimento e desenvolvimento na caderneta de saúde da criança \\ Registro de los datos de crecimiento y desarrollo en la cartilla de salud del niño
}

De Revista Gaúcha

D0l: $\quad$ http://dx.doi.org/10.1590/1983-

1447.2015.02.48427 a Nurse. Master of Nursing Practice. Professor of the Nursing Course at the Centro Universitário de Várzea Grande (UNIVAG). Cuiabá, MT, Brazil.

${ }^{b}$ Nurse. Doctor of Nursing Practice. Professor of the postgraduate programme of the Faculty of Nursing at the Universidade Federal de Mato Grosso (UFMT) Researcher of CNPq. Cuiabá, MT, Brazil.

\section{ABSTRACT}

Objective: The aim was to analyse the input of growth and development data in the Child Health Handbook.

Method: This is a cross-sectional study conducted in Cuiabá, Brazil, on August 13, 2011, with the application of a questionnaire and direct observation of 950 handbooks. We included children under one year of age who resided in Cuiabá, accompanied by their mothers or guardians who were in possession of the handbook. Data were analyzed by calculating the prevalence ratio (PR) and Chi-Square test, with a significance level set at 5\%. The project was approved by the Ethics Committee under Opinion No. 882/2010. Results: Of the analyzed handbooks, $95.4 \%$ of the development data and $79.6 \%$ of the data in the growth charts were incomplete or missing.

Conclusion: The low rate of growth and development data input in the handbooks reveals the need to create awareness among the population, health care professionals and managers on the importance of handbooks, and the need to invest in training and the empowerment of professionals in relation to its proper use.

Keywords: Child health. Growth and development. Public health surveillance. Health records, personal. Primary health care.

\section{RESUMO}

Objetivo: Analisar o preenchimento dos dados do crescimento e desenvolvimento na caderneta de saúde da criança.

Método: Estudo transversal, realizado em Cuiabá, Brasil, em 13 de agosto de 2011, com aplicação de formulário e observação direta de 950 cadernetas. Foram incluídas crianças menores de um ano, residentes em Cuiabá, acompanhadas da mãe ou do responsável e de posse da caderneta. Os dados foram analisados calculando-se a razão de prevalência (RP) e teste Qui-Quadrado, com nível de significância de 5\%. 0 projeto foi aprovado por Comitê de Ética sob o parecer n ${ }^{\circ} 882 / 2010$.

Resultados: Das cadernetas analisadas, 95,4\% do desenvolvimento e 79,6\% dos gráficos de crescimento estavam com preenchimento incompleto ou ausente.

Conclusão: 0 baixo índice de preenchimento dos indicadores, crescimento e desenvolvimento, reforça a necessidade de sensibilização da população, de profissionais e gestores da saúde para a importância da caderneta, bem como investimentos na formação e capacitação dos profissionais quanto ao seu uso adequado.

Palavras-chave: Saúde da criança. Crescimento e desenvolvimento. Vigilância em saúde pública. Registros de saúde pessoal. Atenção primária à saúde.

\section{RESUMEN}

Objetivo: Analizar el relleno de los datos del crecimiento y desarrollo en la Cartilla de Salud del Niño.

Método: Estudio transversal, realizado en Cuiabá, Brasil, en 13 de agosto de 2011, con aplicación de cuestionario y observación directa de 950 cartillas. Se incluyeron niños menores de un ano, residentes en Cuiabá, acompañadas de la madre o responsable y juntamente con la cartilla. Los datos fueron analizados calculándose la razón de prevalencia (RP) y prueba Cui-Cuadrado, con nivel de significancia del 5\%. El proyecto fue aprobado por el Comité de Ética bajo el Parecer no 882/2010.

Resultados: De las cartillas analizadas, $95,4 \%$ del desarrollo y $79,6 \%$ de los gráficos de crecimiento, estaban con relleno incompleto 0 ausente.

Conclusión: El bajo índice de rellenos indicadores de crecimiento y desarrollo refuerza la necesidad de sensibilización de la población, profesionales y gestores de la salud para la importancia de la cartilla, así como inversiones en la formación y capacitación de los profesionales cuanto a su uso adecuado.

Palabras clave: Salud del niño. Crecimiento y desarrollo. Vigilancia en salud pública. Registros personales de salud. Atención primaria de salud. 


\section{DINTRODUCTION}

The monitoring of growth and development serves as a reference for the biological, affective, psychological and social aspects of a child's health ${ }^{(1)}$. The monitoring of anthropometric data in standardized growth curves has become a screening test in the promotion of health, since individual curves, especially of weight, are sensitive indicators of the health status of children ${ }^{(1)}$.

The anthropometric data recorded on growth charts have been used in Brazil since the mid-1980s, after the implementation of the Programa de Atenção Integral à Saúde da Criança (PAISC), or the Comprehensive Children's Care Programme, which initially provided the Child Card, and subsequently implemented the Child Health Handbook in $2005^{(1-2)}$.

The Child Card only contained a graph for monitoring the growth of children under five. In 2005, however, the entire card was reviewed and transformed into the Child Health Handbook to promote comprehensive monitoring of children's health. It is currently the main instrument used to monitor children's health in the national primary care system ${ }^{(2)}$.

In 2007, the Ministry of Health introduced the second version of the handbook that included the new growth curves proposed by the World Health Organization (WHO) in 2006. The revised handbook contained graphs of weight, height and cephalic perimeter according to age, information on birth records, rights of the parents and child, and data on the first days of life of the newborn. It also contained guidelines for child development and stimulation, a healthy diet, and breastfeeding and weaning; space for notes on clinical intercurrences, treatment, prophylactic supplementation of iron and vitamin A, and the basic vaccination calendar ${ }^{(2-3)}$.

The handbook went through another makeover in 2009, which resulted in the inclusion of a basic guide to monitor children with special needs, such as children with Down Syndrome and Autism; the body mass index chart by age; and all the growth charts proposed by the WHO represented in z scores rather than percentile. The age group for monitoring children was also expended (to 10 years of age) and the original handbook was changed to two different handbook versions, one for each sex ${ }^{(3)}$.

The handbook is essential for monitoring growth and development because it contains all the significant data and events related to children's health ${ }^{(3)}$. However, for the handbook to effectively allow monitoring, it must be used in all consultations and contain adequate and complete records from birth until the age of 10 .
Studies on the use and completion of the handbooks and its predecessor, the Child Card, mostly reveal flaws with regard to data on pregnancy, childbirth and the newborn, namely incomplete or absent data on development and in the growth charts ${ }^{(4-6)}$.

Studies that specifically address the monitoring of growth and development based on primary care for children in the health care services reveal that the absence or incompleteness of data for this indicator in the handbook is widespread ${ }^{(7,9)}$.

The importance of controlling and monitoring growth and development to assess the health condition of children, the deficiencies detected in these studies with regard to recording this data, and the scarcity of research on the completion of growth and development data in the handbook in the current scenario justify the present study. The results of this study can support the planning and evaluation of the activities of municipal health care units in relation to children's care, especially with regard to the handbook, which is the most important nationwide instrument for monitoring children's health in the context of primary care.

Given the importance of the handbook as a strategy to monitor and promote the comprehensive health of children, the aim of this study is to analyze the completion of growth and development data in the Child Health Handbook.

\section{METHOD}

This is a descriptive cross-sectional study that originated from a master's thesis ${ }^{(10)}$ developed in family health units in the city of Cuiabá - MT, Brazil. The municipality has 63 family health units (60 in the urban area and 3 in the rural area). The units in the urban area are divided into 4 health regions (North - 13; South - 21; East - 15, and West -11). The sample of units was probabilistic (stratified random sampling) covering $60 \%$ of the units drawn in the 4 health regions, namely 8 in the North Region, 13 in the South Region, 10 in the East Region and 7 in the West Region, totalling 38 units.

The total number of children under the age of one from the drawn units was considered to define the number of children who would participate in the study. At that time, this corresponded to 2490 children who were expected to appear at the units on the day of a vaccination campaign, according to the estimated target of the municipal secretariat of health. The sample was composed of all the children who participated in the campaign in the 38 selected units. The final selection of participants was effectively 
made on the day of data collection based on the following inclusion criteria: under the age of one, residing in the city of Cuiabá, accompanied by the mother or guardian, and in possession of the handbook versions 2007 or 2009. A total of 1057 children under the age of one appeared at the units for vaccination. After applying the criteria for inclusion and excluding those who did not want to participate in the study and the forms that were discarded due to a missing variable, the study sample totalled 950 children under the age of one.

The research was conducted on August 13, 2011, D-day of the 2 nd phase of the national campaign for vaccination against Polio. Data were collected simultaneously in the 38 selected vaccination units using a form that was completed by the mothers or guardians of the children included in the study, and through direct observation of the handbook. Data were collected by 38 volunteers, nurses and previously trained nursing students.

The form for the mothers and guardians contained 43 questions that were divided into the following 7 blocks: Block A - Unit characterization; Block B - Child identification data; Block C - Social, economic and demographic data of the mother; Block D - Handbook data (identification, data on pregnancy, childbirth and the puerperium, and birth data); Block E - Assessment of development data; Block F - Assessment of growth data; Block $G$ - Assessment of vaccine data. In blocks $\mathrm{D}$ to $\mathrm{G}$, the questions provided three alternatives, namely complete, incomplete and missing, which required the direct observation of the information in the handbook. The answers to the questions of blocks $B$ and $C$ were obtained from the forms completed by the mothers or guardians, and the answers to the questions of blocks $D, E, F$ and $G$ required direct observation of the handbook. The information from blocks A, B, C, E and F were used for this article.

The Manual for Use of the Child Handbook was used to evaluate completion of the handbook. This manual indicates the criteria for the data included in the handbook $^{(2)}$ as being complete, incomplete or missing. Notes are considered incomplete when one of the items is missing. The reference for analyzing the quality of data included in the handbook was a scoring system based on a study carried out in the municipality of Belo Horizonte $(M G)^{(6)}$, which attributed the value 1 for items filled in correctly and value 0 for items that were incorrectly filled in or not filled in. The score of $60 \%$ or less of the items completed ( $\leq 12$ points) and the score of $60 \%$ or more of the items completed (> 12 points) was established to obtain the total sum of each item.

In this study, the development records were evaluated as follows: "0" (absent $=$ no items filled), "1" (incomplete $=1$ item filled) and "2" (total = 2 items or more filled). Therefore, the development curve was considered complete when the 2 or more of the items in the handbook had been filled in (out of 4), according to the child's age at the time of data collection. The maximum score was " 2 " and the minimum score was " 0 ". The cut-off points were $\leq 0.8$ points (representing $\leq 40 \%$ completed items) and $>0.8$ points (representing $60 \%>$ completed items).

For the data records of the growth curve, the scores were added (0 -missing; 1 - incomplete; 2 - complete), with a range of 0 to 8 . The handbook was considered complete when it included at least one weight input every three months, with a minimum of 4 records in the first year of life. A cut-off point was used to establish the level of completion: $\leq 3$ points (representing less than $40 \%$ of items completed) and $>3$ points (representing $60 \%$ or more completed items).

The definition of the cut-off point for the growth and development indicators was based on the statistical distribution of scores, since guidance indicators were not found in literature.

The collected data were tabulated and analyzed using the Statistical Package for Social Sciences (SPSS) version 17.0. The association between variables was analysed using the prevalence ratio (PR), Chi-square test, $p$-value calculation and the $95 \%$ confidence interval (C195). Values of $p$ that were equal or lower than 0.05 were considered as values of statistical significance.

This study is part of the matrix project Avaliação da atenção à criança na rede básica de saúde de Cuiabá, MT, com ênfase em sua organização, assistência e nas práticas de enfermagem, approved by the Research Ethics Committee of the Hospital Universitário Julius Muller, Opinion No. 882/2010, in accordance with the guidelines of Resolution 196/96 of the National Health Council, in force at the time of research. The interviewed mothers/guardians were oriented on the goals and methods of research and freely signed a consent form.

\section{QRESULTS}

A total of 950 handbooks were analyzed in relation to the growth curve and a total of 929 handbooks were analysed in relation to the development curve. The 2007 handbook includes age group stratification while the 2009 does not include this stratification, so 21 children who used the 2007 model were excluded from this analysis.

Table 1 presents the characteristics of the mothers and children. Most of the mothers were over the age of 19 (85.9\%), had more than 7 years of schooling (80.1\%), 
Table 1 - General characteristics of the studied sample. Cuiabá - Mato Grosso, Brazil, 2011 ( $n=950$ )

\section{Variables}

n

\section{Age of mothers (years)}

$\leq 19$

$>19$

Years of schooling of the mothers

$\leq 7$

$>7$

Age of the children

$\leq 6$ months

$>6$ months

Sex of the children

Boy

Girl

Number of children

One

Two or more

Mother works outside the home

Yes

No

Family income* $(n=910)$
134

816

189

761

572

378

488

462

436

514

388

562

610

300

\section{$\%$}

Total

950

85.9

19.9

80.1

60.2

39.8

51.4

48.6

950

45.9

54.1

950

950

59.2

67.0

33.0

910

Source: Research data, 2011.

*Did not respond. ** Minimum wage at the time of the study BRL 545.00 .

had two or more children (54.1\%), did not work outside the home (59.2\%), and had a household income that was equal or lower than 2 minimum wages (67.0\%). As for the children, there was a predominance of boys ( $51.4 \%)$, aged $\leq 6$ months (60.2\%).

Table 2 shows that $95.4 \%$ of the 929 handbooks had incomplete or missing information related to development. Only the variable number of children showed a statistical significance, indicating a risk ( $p=0.034 / \mathrm{PR}=1.03)$ of non-completion.

Of the 950 handbooks investigated, 756 (79.6\%) had missing or incomplete data in the growth chart and only the variable age of children showed a statistical significance, suggesting the risk to not fully completing the handbooks (Table 3).

Completion of the weight in numbers and whether the curve was drawn were also observed. Of the 950 hand- books, $76.1 \%$ did not have the handwritten weight value and $70.5 \%$ did not have a hand-drawn curve in the graph.

\section{DISCUSSION}

The Health Ministry recommends that the development of infants must be monitored during all the consultations in order to detect any changes and offer guidance to encourage the mothers and/or family members, and, in severe cases, refer the child as early as possible ${ }^{(1)}$.

However, the results of this research show that the recording of a child's neuro-psychomotor development is being neglected by health professionals, since this information was not found in $95.0 \%$ of the investigated handbooks. This finding is supported by the findings of other studies conducted in Feira de Santana (BA) and Belo Horizonte $(\mathrm{MG})$, Brazil, where the absence of records for this 
Table 2 - Distribution of the variables of the mothers and children according to completion of development data in the Child Health Handbook. Cuiabá - Mato Grosso, Brazil, 2011 ( $n=929)$

\begin{tabular}{|c|c|c|c|c|c|}
\hline \multirow[b]{2}{*}{ Variables } & \multicolumn{5}{|c|}{ Completion of development data } \\
\hline & $\begin{array}{l}\text { Incomplete } \\
\text { or missing } \\
\text { (Score } \leq \mathbf{0 . 8} \text { ) }\end{array}$ & $\begin{array}{c}\text { Complete } \\
\text { (Score } \leq \mathbf{0 . 8} \text { ) }\end{array}$ & Chi-square & p value & $\mathrm{PR}^{*}(\mathrm{Cl} 195 \%)$ \\
\hline \multicolumn{6}{|l|}{ Age of mothers } \\
\hline$\leq 19$ & 130 & 3 & 1.98 & 0.159 & $1.03(1.00-1.06)$ \\
\hline$>19$ & 756 & 40 & & & \\
\hline \multicolumn{6}{|c|}{ Years of schooling of the mothers } \\
\hline$\leq 7$ & 173 & 9 & 0.051 & 0.821 & $1.00(0.96-1.03)$ \\
\hline$>7$ & 713 & 34 & & & \\
\hline \multicolumn{6}{|l|}{ Number of children } \\
\hline One & 414 & 13 & 4.492 & 0.034 & $1.03(1.00-1.06)$ \\
\hline Two or more & 472 & 30 & & & \\
\hline \multicolumn{6}{|l|}{ Age of the children } \\
\hline$\leq 6$ months & 527 & 31 & 2.72 & 0.099 & $0.98(0.95-1.00)$ \\
\hline$>6$ months & 359 & 12 & & & \\
\hline \multicolumn{6}{|l|}{ Sex of the children } \\
\hline Male & 451 & 27 & 2.320 & 0.128 & $0.98(0.95-1.01)$ \\
\hline Female & 435 & 16 & & & \\
\hline \multicolumn{6}{|l|}{ Family income ${ }^{* * *}(n=892)$} \\
\hline$\leq 2$ minimum wages $* * *$ & 571 & 30 & 1.691 & 0.193 & $0.98(0.95-1.01)$ \\
\hline$>2$ minimum wages & 282 & 9 & & & \\
\hline \multicolumn{6}{|c|}{ Mother works outside the home } \\
\hline Yes & 362 & 16 & 0.226 & 0.634 & $1.01(0.98-1.04)$ \\
\hline No & 524 & 27 & & & \\
\hline
\end{tabular}

Source: Research data, 2011

*Prevalence Ratio ** Of the 929 mothers interviewed, 37 did not know the family income. ${ }^{* * *}$ Minimum wage at the time of the study BRL 545.00.

indicator was registered in $92.2 \%$ and $81.1 \%$ of the handbooks, respectively ${ }^{(4.6)}$.

Contrarily, a study conducted in France shows that development records were found in $74.0 \%$ to $93.0 \%$ of the handbooks of French children from the ages of 1 to 4, which reveals the importance that French professionals attribute to this indicator ${ }^{(11)}$.

The precariousness of records on child development was also observed while evaluating the charts. Research conducted in João Pessoa (PB) with the purpose of analyzing growth and development data recorded by nurses showed that data on child development were absent in $100 \%$ of the files ${ }^{(7)}$. A similar result was also found in the city of Pelotas (RS), where $94.0 \%$ of children under one year who were attended at a primary care unit did not have any form of child development data included in their medical files ${ }^{(12)}$. In turn, a study that analyzed the records of growth and development in nursing consultations for children under the age of two at family health units in Cuiaba - MT, Brazil, showed that $59.1 \%$ of the development records in the files were incomplete ${ }^{(8)}$.

Health data records are a means of communication used by professionals during their practices. Consequently, and considering that these records have a direct impact on the quality of the provided care, this information must be correctly recorded ${ }^{(13-14)}$. 
Table 3 - Distribution of the variables of the mothers and children according to completion of growth development data in the Child Health Handbook. Cuiabá - Mato Grosso, Brazil, 2011 ( $n=950$ )

\begin{tabular}{|c|c|c|c|c|c|}
\hline \multirow[b]{2}{*}{ Variables } & \multicolumn{5}{|c|}{ Completion of data in the growth curve } \\
\hline & $\begin{array}{l}\text { Incomplete } \\
\text { or missing } \\
\text { (Score } \leq 3 \text { ) }\end{array}$ & $\begin{array}{l}\text { Complete } \\
\text { (Score } \leq 3 \text { ) }\end{array}$ & Chi-square & p value & PR* (Cl95\%) \\
\hline \multicolumn{6}{|l|}{ Age of mothers } \\
\hline$\leq 19$ & 101 & 33 & 1.698 & 0.193 & $0.94(0.85-1.04)$ \\
\hline$>19$ & 655 & 161 & & & \\
\hline \multicolumn{6}{|c|}{ Years of schooling of the mothers } \\
\hline$\leq 7$ & 143 & 46 & 2.228 & 0.136 & $0.94(0.86-1.03)$ \\
\hline$>7$ & 613 & 148 & & & \\
\hline \multicolumn{6}{|l|}{ Number of children } \\
\hline One & 337 & 99 & 2.590 & 0.108 & $0.95(0.89-1.01)$ \\
\hline Two or more & 419 & 95 & & & \\
\hline \multicolumn{6}{|l|}{ Age of the children } \\
\hline$\leq 6$ months & 506 & 66 & 69.796 & 0.000 & $1.34(1.24-1.45)$ \\
\hline$>6$ months & 250 & 128 & & & \\
\hline \multicolumn{6}{|l|}{ Sex of the children } \\
\hline Male & 387 & 101 & 0.047 & 0.829 & $0.99(0.93-1.06)$ \\
\hline Female & 369 & 93 & & & \\
\hline \multicolumn{6}{|l|}{ Family income $(n=910)^{* *}$} \\
\hline$\leq 2$ minimum wages $* * *$ & 487 & 123 & 0.031 & 0.86 & $0.99(0.93-1.06)$ \\
\hline$>2$ minimum wages & 241 & 59 & & & \\
\hline \multicolumn{6}{|c|}{ Mother works outside the home } \\
\hline Yes & 316 & 72 & 1.403 & 0.236 & $1.04(0.98-1.11)$ \\
\hline No & 440 & 122 & & & \\
\hline
\end{tabular}

Source: Research data, 2011.

*Prevalence Ratio ${ }^{* *} 0$ f the 950 mothers interviewed, 40 did not know the family income. ${ }^{* * *}$ Minimum wage at the time of the study BRL 545.00.

In this study, only the variable number of children showed a statistical significance, suggesting the risk ( $p$ $=0.034 / \mathrm{PR}=1.03$ ) of not completing development data. This also shows that the professionals focused more attention on filling in this information in the handbooks for the mothers of two or more children, contrary to the results found in Feira de Santana (BA), in which the professionals showed a greater concern for completing this indicator in the handbooks of first-time mothers ${ }^{(4)}$.

A likely explanation for the association between the number of children and the non-completion of development data can be that mothers with two or more children have more experience and knowledge of children's health, especially in terms of development. Consequently, they tend to be more attentive to this aspect and more demanding with regard to the use of the book by health professionals.

The monitoring of child development is a fundamental activity that should be performed by health professionals in order to promote the proper development of children, and identify and prevent deviations ${ }^{(14)}$. To this end, the professional should take advantage of the moment of filling in the development chart to provide guidance on the skills expected for the age of the child and how the mother/family can engage and stimulate the child in this process. The instrument for monitoring 
development provided in the handbook helps parents to recognize their role in the stimulation of their children's developmental milestones ${ }^{(15)}$.

With regard to growth, it was observed that only $20.4 \%$ of the handbooks contained complete information, which is considered a poor percentage for monitoring this indicator in children under the age of one. This result is contrary to the recommendation of the MS, which establishes that children under the age of one should be evaluated at least once every three months, totaling a minimum of four records in the first year(2).

A low percentage of growth chart input in the handbooks was also observed in a study conducted in the city of Brasília (DF), where only $21.1 \%$ of the charts were properly filled out ${ }^{(16)}$. Even lower percentages were found in a recent study conducted in a small town in the state of São Paulo, in which only one-third of the analysed handbooks contained complete records of anthropometric measurements, and less than $10 \%$ had correctly filled in weight and height charts ${ }^{(17)}$.

Only the variable age of children demonstrated a statistical significance, suggesting the risk of not filling in the growth indicator. The age group that demonstrated the greatest probability of incorrectly or incompletely filling in this record was children aged six months or less, with a rate of $53.3 \%$. This percentage is greater than the percentage found in the study in Feira de Santana (BA), in which 21.4\% of handbooks of children under six months did not contain complete growth data ${ }^{(4)}$. In turn, research conducted in Brasilia (DF) showed that the proper completion of growth data decreases as the child's age increases, and the highest rate of correct completion was found in the charts of children under 6 months of age ${ }^{(16)}$, which is contrary to the results found in the present study. Research conducted in France also confirmed the tendency of reducing data completion in the handbook as the child gets older ${ }^{(11)}$.

This divergence with other studies draws some attention because concerns for the health of children, both of the parents and healthcare professionals, is naturally greater in the early stages of life. During this period, children tend to grow and develop at a more alarming rate, which justifies more frequent monitoring and the continued and resolutive attention of the healthcare team. The minimum consultations calendar for monitoring the health of children recommended by the Ministry of Health foresees a greater number of consultations in the first years of a child's life ${ }^{(1)}$.

Furthermore, it is during the first year of life that children receive most of their vaccines, which requires monthly return appointments to the healthcare services, and provides more opportunities for using the handbook as an instrument of care.

Another relevant aspect in infant monitoring is the growth curve. In this study, less than 1/3 of the handbooks contained handwritten weight figures and a handdrawn growth curve. This is worrisome, because without the addition of these elements there is no way to correctly assess longitudinal growth. The MS recommends that professionals construct the growth curves from the weight score in the graph, connecting the dots to reveal the growth trend of the child against the established standards ${ }^{(2)}$.

A possible explanation for the low percentage of growth chart input could be related to the difficulties of health professionals in dealing with the new concepts incorporated into the handbook, such as the reference curves in z-scores and the body mass index chart by age $(\mathrm{BMI})^{(18)}$.

The periodic assessment of weight gain helps professionals monitor the child's evolution and identify children with a greater risk of morbimortality by recognizing early signs of danger. Consequently, monitoring must follow a minimum calendar of consultations and be properly registered in the medical files and in the handbook ${ }^{(1)}$.

Despite the importance of these handbooks for monitoring and promoting the health of children, literature reveals a disturbing situation regarding their use ${ }^{(15,19)}$. Studies show that the main factors that hinder the proper use of handbooks by health professionals are a lack of training for using this instrument, the unavailability of handbooks in primary care units, non-use of the book by all healthcare team members and lack of knowledge on the existence of handbooks by mothers/families ${ }^{(18,20)}$.

The precarious use of the handbooks revealed in this study may indicate that actions geared specifically toward monitoring the growth and development of children are not reaching the majority of infants under the age of one in the municipality. This condition causes concern, since the handbook is the only instrument for monitoring the growth and development of children. Therefore, the correct and complete record of data by health professionals is of fundamental importance.

The proper use of the handbook is essential to promote comprehensive monitoring of children's health, but in order to fulfil that function, healthcare professionals must participate and show commitment toward its implementation ${ }^{(4)}$. A greater appreciation of this document by healthcare managers is also required in order to provide the necessary conditions for their use and subsequently ensure good quality healthcare for children. 
The findings of this study provide greater insight into the particularities of this subject because it was not limited to describing the percentages of growth and development data input, and included scores used to evaluate the quality of data input. This enables the analysis of a range of relevant data for the health of children, and reveals the urgent need to implement strategies to organize primary care services in the municipality with actions that target the use of this handbook for monitoring children's growth and development, especially of infants under the age of one.

\section{CONCLUSION}

Results showed that $95.4 \%$ and $79.6 \%$ of the handbooks had incomplete or missing information on the development and growth of children, respectively. Only two variables showed a statistical significance, suggesting a risk of not completing the handbooks: age of the child for the growth data and number of children for the development data.

The low rate of input for growth and development in the handbook detected in this study suggests the inadequate monitoring of children, which may compromise the quality of care and impair the assessment of health actions. Furthermore, the handbook is a right of children and its incorrect use by healthcare professionals is a violation of that right.

It is worth mentioning that the faults found in handbooks records reveal the need to create awareness on the importance of this instrument among all those involved in children's healthcare, and to invest in training for the correct usage of the handbooks. It is also necessary to ensure that the handbook is valued and safeguarded by mothers/ families so it can effectively fulfil its role as an instrument of communication, education, vigilance and promotion of healthcare.

This study has the limitations that are inherent to cross-sectional studies. Despite this limitation, the results can be added to past studies to support the planning of actions and policies for children, and call the attention of professionals who directly assist this population on the importance of using the handbook correctly to enable families to take better care of their children, and on the practices of professionals in the context of primary care.

We also believe that the results of this study can be applied to practices that improve the quality of children's care and healthcare education. Moreover, the results indicate the need for new studies on this subject to include children of other age groups and the analysis of different variables that shed light on the causes that prevent the correct use of these handbooks.

\section{REFERENCES}

1. Ministério da Saúde (BR). Saúde da criança: crescimento e desenvolvimento. Braślia, DF; 2012. Cadernos de Atenção Básica, n 33.

2. Ministério da Saúde (BR). Secretaria de Atenção à Saúde. Departamento de Ações Programáticas Estratégicas. Área Técnica Saúde da Criança e Aleitamento Materno. Manual para utilização da caderneta de saúde da criança. Brasilia, DF; 2005.

3. Ministério da Saúde (BR). Secretaria de Atenção à Saúde. Departamento de Açōes Programáticas Estratégicas. Área Técnica Saúde da Criança e Aleitamento Materno. Caderneta de saúde da criança. Braślia, DF; 2009.

4. Vieira GO, Vieira TO, Costa MCO, Santana Netto PV, Cabral VA. Uso do cartão da criança em Feira de Santana, Bahia. Rev Bras Saude Mater Infant. 2005;5(2):177-84.

5. Goulart LMHF, Alves CRL, Viana MRA, Moulin ZS, Carmo GAA, Costa JGD, et al. Caderneta de saúde da criança: avaliação do preenchimento dos dados sobre gravidez, parto e recém-nascido. Rev Paul Pediatr. 2008;26(2):106-12.

6. Alves CRL, Lasmar LMLBF, Goulart LMHF, Alvim CG, Maciel GVR, Viana MRA, et al. Qualidade do preenchimento da caderneta de saúde da criança e fatores associados. Cad Saúde Pública. 2009;25(3):583-95.

7. Lima GGT, Silva MFOC, Costa TNA, Neves AFGB, Dantas RA, Lima ARSO. Registros do enfermeiro no acompanhamento do crescimento e desenvolvimento: enfoque na consulta de puericultura. Rev Rene. 2009;10(3):17-24.

8. Moreira MDS, Gáiva MAM. Acompanhamento do crescimento e desenvolvimento infantil: análise dos registros das consultas de enfermagem. Rev Pesqui Cuid Fundam. 2013;5(2):3757-66.

9. Modes PSSA, Gaíva MAM. Satisfação das usuárias quanto à atenção prestada à criança pela rede básica de saúde. Esc Anna Nery Rev Enferm. 2013:17(3):455-65.

10. Abud SM. Análise do preenchimento da caderneta de saúde de crianças atendidas pelas equipes de saúde da família do município de Cuiabá-MT [dissertação]. Cuiabá (MT): Faculdade de Enfermagem, Universidade Federal de Mato Grosso; 2012.

11. Vincelet C, Tabone MD, Berthier M, Bonnefoi MC, Chevallier B, Lemaire JP, et al. Le carnet de santé de l'enfant est-ill informative? évaluation dans différentes structures de prévention et de soins. Arch Pédiatr. 2003;25(10):403-9.

12. Ceia MLM, Cesar JA. Avaliação do preenchimento dos registros de puericultura em unidades básicas de saúde em Pelotas, RS. Rev AMRIGS. 2011;55(3):244-9.

13. Oliveira VC, Cadette MMM. Anotaçōes do enfermeiro no acompanhamento do crescimento e desenvolvimento infantil. Acta Paulista de Enfermagem. 2009;22(3):301-6.

14. Clendon J, Dignam D. Child health and development record book: tool for relationship building between nurse and mother. Journal of Advanced Nursing. 2010;66(5):968-77.

15. Gaiva MAM, Silva FB. Caderneta de saúde da criança: revisão integrativa. Rev Enferm UFPE On Line. [Internet]. 2014 [cited in 2015 fev. 5];8(3):742-9. Available at: http://www.revista.ufpe.br/revistaenfermagem/index.php/revista/article/ view/5357/pdf_4773

16. Sardinha LMV, Pereira MG. Avaliação do preenchimento do cartão da criança no Distrito Federal. Braślia Méd. 2011;48(3):246-51. 
17. Palombo CNT, Duarte LS, Fujimori E, Toriyama ATM. Uso e preenchimento da caderneta de saúde da criança com foco no crescimento e desenvolvimento. Rev Esc Enferm USP. 2014;48(nesp):60-7.

18. Abreu TGT, Viana LS, Cunha CLFC. Desafios na utilização da caderneta de saúde da criança: entre o real e o ideal. J Manag Prim Health Care. 2012;3(2):80-3.
19. Reichert APS, Almeida AB, Souza LC, Silva MEA, Collet N. Vigilância do crescimento infantil: conhecimento e práticas de enfermeiros da atenção primária à saúde. Rev Rene. 2012;13(1):114-26.

20. Linhares A0, Gigante DP, Bender E, Cesar JA. Avaliação dos registros e opinião das mães sobre a caderneta de saúde da criança em unidades básicas de saúde, Pelotas, RS. Rev AMRIGS. 2012:56(3):245-50.

\section{Author's address:}

Maria Aparecida Munhoz Gaíva

Rua 59, 215/303, Jardim Goiás

74810-260 Goiânia - GO

Email:mamgaiva@yahoo.com.br
Received: 07.07.2014

Approved: 17.04.2015 